\title{
Frequency of ABO blood group and Rhesus factor (D) in patients of type 2 diabetes mellitus attending tertiary care teaching hospital of South India
}

\author{
Shrimanjunath Sankanagoudar ${ }^{1, *}$, Shivanand Mali ${ }^{2}$ \\ ${ }^{\mathbf{1}}$ Assistant Professor, Dept. of Biochemistry, All India Institute of Medical Sciences (AIIMS), Jodhpur, Rajasthan, ${ }^{2}$ Post Graduate \\ Student, Dept. of Biochemistry, Jawaharlal Nehru Medical College, (JNMC), Balagavi, Karnataka, India \\ *Corresponding Author: \\ Email: doc_manjunath@yahoo.co.in
}

Received: $28^{\text {th }}$ December, 2017

Accepted: $20^{\text {th }}$ March, 2018

\begin{abstract}
Introduction and Objective: Diabetes mellitus (DM) is a group of metabolic diseases characterized by hyperglycemia resulting from defects in insulin secretion, insulin action, or both. After discovery of ABO human blood group system by Landsteiner, many researchers had tried to correlate between ABO phenotype and disease susceptibility. Many reports have appeared in recent past suggesting an association between blood groups and DM but published literature has produced conflicting results. The objective of the present study is to estimate the prevalence of $\mathrm{ABO}$ and $\mathrm{Rh}$ (D) blood group type among diabetics attending tertiary care teaching hospital.

Materials and Methods: With institutional ethical committee approval and permission from Medical Director, we collected data of diabetic patients from medical records section for a 12 months period from $1^{\text {st }}$ Jan 2015 to $31^{\text {st }}$ Dec 2015 . Study design was descriptive and retrospective. Data of $\mathrm{ABO}$ and $\mathrm{Rh}(\mathrm{D})$ blood groups were represented in simple number and percentage distribution.

Results: A total of 1,038 diabetic patients' medical records were collected during the study period for ABO grouping and Rh (D) typing. Out of these $59.34 \%$ were males and $\mathrm{Rh}$ (D) positive was seen in $95.56 \%$. The frequency of blood groups $\mathrm{O}$, A, B, AB was $32.36 \%, 29.95 \%, 29.28 \%$ and $8.37 \%$ respectively. The most prevalent blood group in both males and females was ' $O$ ' and least prevalent was 'AB' blood group.

Conclusion: Our study findings suggested DM was more frequently seen in individuals with blood group ' $\mathrm{O}$ ' and these individuals should be closely monitored by the treating physicians. The trend of observed prevalent percentage of blood groups for $\mathrm{DM}$ was $\mathrm{O}>\mathrm{A} \geq \mathrm{B}>\mathrm{AB}$.
\end{abstract}

Keywords: ABO blood groups, $\mathrm{Rh}$ (D) typing, Diabetes, Tertiary care hospital, Retrospective.

\section{Introduction}

Diabetes mellitus (DM) is a group of metabolic diseases characterized by hyperglycemia resulting from defects in insulin secretion, insulin action, or both. According to World Health Organization's fact sheet, DM was the direct cause of 1.5 million deaths ${ }^{1}$ with more than $80 \%$ of deaths occurring in low and middleincome countries. ${ }^{2}$ By 2030, it will be the $7^{\text {th }}$ leading cause of death. ${ }^{3}$

According to statistics from the International Diabetes Federation (IDF) in India the prevalence of diabetes increased tenfold, from $1.2 \%$ to $12.1 \%$, between 1971 and $2000 .{ }^{4}$ India has more diabetics than any other nation of the world and so it is known as "Diabetes capital of the world". It was estimated that 61.3 million people aged 20-79 years live with diabetes in India (2011 estimates). This number is expected to increase to 101.2 million by $2030^{5}$ and 77.2 million people in India are said to have pre-diabetes. ${ }^{6}$ About 1 million people died from diabetes in India in 2012. ${ }^{6}$ All these statistics leads to a potential epidemic status of $\mathrm{DM}$ in India.

In 1900, Landsteiner discovered the major human blood group system i.e. ABO. Since then many researchers had tried to correlate between $A B O$ phenotype and disease susceptibility. There are certain diseases which show strong evidence of association with the $\mathrm{ABO}$ blood groups, notably duodenal ulcer with blood group ' $\mathrm{O}^{77}$ and carcinoma of the stomach with blood group ' $A{ }^{\prime} .{ }^{8}$ Many reports have appeared in recent years suggesting an association between blood groups and DM. ${ }^{9-11}$ However, extensive search on published literature produced conflicting results. This study has been done to know the frequency of $\mathrm{ABO}$ and $\mathrm{Rh}$ (D) blood group in diabetics of local population attending a tertiary care teaching hospital.

\section{Materials and Methods}

This is a retrospective study carried out during the period March 2016 - March 2017 in department of Biochemistry, KLE University's J. N. Medical college and Dr. Prabhakar Kore Charitable Hospital, Belagavi, Karnataka. The study was approved by the Institutional Ethics Committee on human subject research, J.N.Medical College, Belagavi, India. The medical records of DM patients whose blood group was examined between $1^{\text {st }}$ January 2015 to $31^{\text {st }}$ December 2015 were collected after getting permission from Medical Director, KLE hospital. A total of 1038 DM patients' medical record data were collected and analysed for frequency of $\mathrm{ABO}$ blood group and $\mathrm{Rh}$ (D) typing. 


\section{Statistical Analysis}

Data of $\mathrm{ABO}$ and $\mathrm{Rh}$ (D) blood groups were represented in simple number and percentage distribution.

\section{Results}

A total of 1038 DM patients' medical record data were collected and analysed for frequency of $\mathrm{ABO}$ blood group and $\mathrm{Rh}$ typing in this study. Table 1 shows percentage distribution of data according to gender and $\mathrm{Rh}$ (D) factor. Out of total 1038, $616(59.34 \%)$ were male and 992 (95.56\%) were Rh (D) positive.

Table 1: Percentage distribution of data according to gender and $\mathrm{Rh}$ (D) factor

\begin{tabular}{|l|c|c|c|}
\hline Data & Groups & Number & Percentage (\%) \\
\hline \multirow{3}{*}{ Sex } & Male & 616 & 59.34 \\
\cline { 2 - 4 } & Female & 422 & 40.66 \\
\cline { 2 - 4 } & Total & $\mathbf{1 0 3 8}$ & $\mathbf{1 0 0}$ \\
\hline \multirow{3}{*}{ Rh } & $\mathrm{Rh}^{+v e}$ & 992 & 95.56 \\
\cline { 2 - 4 } & $\mathrm{Rh}^{\text {-ve }}$ & 46 & 4.44 \\
\cline { 2 - 4 } & Total & $\mathbf{1 0 3 8}$ & $\mathbf{1 0 0}$ \\
\hline
\end{tabular}

Data represented in simple number and percentage of total data collected $(\mathrm{n}=1038)$

Table 2 summarizes the distribution of $\mathrm{ABO}$ blood group and $\mathrm{Rh}(\mathrm{D})$ typing among $\mathrm{DM}$ patients. The frequency of blood group ' $\mathrm{O}$ ' in our study was the highest i.e. $32.36 \%(30.73 \%$ ' $O$ ' $\mathrm{Rh}(\mathrm{D})$ positive and
$1.63 \%$ ' $\mathrm{O}$ ' $\mathrm{Rh}(\mathrm{D})$ negative) and blood group ' $\mathrm{AB}$ ' was the lowest i.e. $8.37 \%$ ( $7.89 \%$ 'AB' $\mathrm{Rh}(\mathrm{D})$ positive and $0.48 \%$ ' $\mathrm{AB}$ ' $\mathrm{Rh}$ (D) negative). The total $\mathrm{Rh}$ (D) negative was $4.44 \%$ (Table 1 and Table 2)

Table 2: ABO blood group and Rh (D) factor distribution among patients of DM

\begin{tabular}{|l|c|c|c|c|}
\hline \multirow{2}{*}{ Blood group } & \multicolumn{2}{|c|}{$\mathbf{R h}^{\text {+ve }}$} & \multicolumn{2}{c|}{$\mathbf{R h}^{\text {-ve }}$} \\
\cline { 2 - 5 } & Number & Percentage (\%) & Number & Percentage (\%) \\
\hline $\mathrm{A}$ & 299 & 28.80 & 12 & 1.15 \\
\hline $\mathrm{B}$ & 292 & 28.13 & 12 & 1.15 \\
\hline $\mathrm{AB}$ & 82 & 7.89 & $\mathbf{5}$ & $\mathbf{0 . 4 8}$ \\
\hline $\mathrm{O}$ & $\mathbf{3 1 9}$ & $\mathbf{3 0 . 7 3}$ & 17 & 1.63 \\
\hline Total & 992 & 95.56 & 46 & 4.44 \\
\hline
\end{tabular}

Table 3 shows the percentage prevalence of $\mathrm{ABO}$ and $\mathrm{Rh}(\mathrm{D})$ positive blood group among male and female DM patients. Among male and female DM patients, blood group ' $\mathrm{O}$ ' was the most prevalent and 'AB' was least prevalent blood group.

Table 3: Percentage prevalence of different blood groups of $\mathrm{Rh}(\mathrm{D})^{\text {tve }}$ in male and female patients of DM $(\mathbf{n}=992)$

\begin{tabular}{|l|c|c|c|c|}
\hline \multirow{2}{*}{ Blood group } & \multicolumn{2}{|c|}{ Males (n=585) } & \multicolumn{2}{c|}{ Females (n=407) } \\
\cline { 2 - 5 } & Number & Percentage (\%) & Number & Percentage (\%) \\
\hline A & 174 & 29.74 & 125 & 30.71 \\
\hline B & 175 & 29.91 & 117 & 28.74 \\
\hline AB & 51 & 8.71 & 31 & 7.61 \\
\hline O & 185 & 31.62 & 134 & 32.92 \\
\hline
\end{tabular}

\section{Discussion}

The purpose of present study was to find the frequency of $\mathrm{ABO}$ blood group and $\mathrm{Rh}(\mathrm{D})$ factor in persons suffering from DM in southern India. ABO blood group system is genetically determined and is inherited in a Mendelian fashion with stable characteristics. ${ }^{12} \mathrm{ABO}$ and $\mathrm{Rh}$ antigen genes are present on different chromosomes i.e. $9^{\text {th }}$ and $1^{\text {st }}$ chromosomes respectively. ${ }^{13}$ All human populations share the same blood group systems but they differ in the frequencies of specific types. The occurrence of $\mathrm{ABO}$ and $\mathrm{Rh}$ groups varies noticeably in different races, ethnic groups, and socioeconomic groups in different parts of the world. The frequencies of $\mathrm{ABO}$ and $\mathrm{Rh}$ blood groups vary from one population to another. The study of distribution of blood groups is important as it plays a vital role in blood transfusion and organ transplantation. There are certain diseases which show strong association with the ABO blood groups such as duodenal ulcer and gastric cancer.

The present study has shown blood group ' $O$ ' $(32.36 \%)$ to be the most common blood group followed by 'A' $(29.95 \%)$, 'B' $(29.28 \%)$ and 'AB' $(8.37 \%)$ in DM in southern India. This prevalence is in 
concordance with the some studies done in India ${ }^{14,15}$ except for the northern region where blood group B was found to be the most common. The study done by Sharma Sandhya et al in the year 2014 had shown the blood group ' $\mathrm{B}$ ' was the most frequent in DM followed by ' $\mathrm{O}$ ', ' $\mathrm{A}$ ' and 'AB' in Jodhpur city' and Shyamal Koley et al reported blood group ' $\mathrm{B}$ ' was more frequent in DM individuals in Madhya Pradesh. ${ }^{16}$ The same results were observed in different parts of India where blood group ' $\mathrm{B}$ ' was more frequent in DM. ${ }^{17}$

Limitations: Sample size and hospital bias were the limitations of our study. We have only considered the patients admitted in the hospital for the present study. Any further study based on this topic should be done by overcoming these limitations and the

findings need to be confirmed by large community based studies.

\section{Conclusion}

The present study suggested DM was more frequently seen in individuals with blood group ' $\mathrm{O}$ ' and the trend of observed prevalent percentage of blood groups for $D M$ was $O>A \geq B>A B$. The individual with blood group ' $\mathrm{O}$ ' should be, closely monitored by the treating physicians.

Acknowledgement: The authors are thankful to Dr. M. V. Jali, Medical Director and CEO, KLE'S Dr. Prabhakar Kore Hospital \& M.R.C for access to the medical records of DM patients and Dr. Sanjay Kambar, Professor, Department of Community Medicine and Dr. Sandip Chindi, Assistant Professor of Medicine, J N Medical College, Belagavi for their valuable suggestions.

Conflicts of Interest: All authors declare no competing or conflicts of interests.

\section{References}

1. World Health Organization. Global Health Estimates: Deaths by Cause, Age, Sex and Country. Geneva. WHO. 2014.

2. Mathers C D, Loncar D. Projections of global mortality and burden of disease from 2002 to 2030. PLoS Med. 2006;3(11):442.

3. Non communicable Diseases in the Southeast Asia Region: Situation and Response. World Health Organization: 2011.

4. David R. Whiting et al. IDF Diabetes Atlas: Global estimates of the prevalence of diabetes for 2011 and 2030. Diabetes Research and Clinical Practice. 2011;4(3):311-321.

5. Anjana RM, Pradeepa R, Deepa M, Datta M, Sudha V, Unnikrishnan R et al. Prevalence of diabetes and prediabetes (impaired fasting glucose and/or impaired glucose tolerance) in urban and rural India: phase I results of the Indian Council of Medical Research-India Diabetes (ICMR-INDIAB) study. Diabetologia. 2011 Dec;54(12):3022-7.
6. “IDF Diabetes Atlas." International diabetes federation. November 2012. Web. March 2013. http://www.idf.org/diabetesatlas 1 diabetes is a huge problem in India.

7. M. S. Jaff, Relation between ABO blood groups and Helicobactorpyroli infection in symptomatic patients. Clin Exp Gastroenterol. 2011;4:221-226.

8. I. Arid, H. Bentall and J. Roberts, A relationship between cancer of stomach and the ABO blood groups, British Medical Journal, 1953;1:799-801.

9. Sharma $\mathrm{S}$ et al, Association between ABO blood groups and diabetes mellitus. Sch J App Med Sci. 2014;2(1A):34-37.

10. Macafee A L. Blood Groups and Diabetes Mellitus. $J$ Clin Path. 1964;17-39.

11. Kamil M, Hamid Ali N, Al-Jamal and Narazah Mohd Y. Association of ABO Blood Groups with Diabetes Mellitus. Libyan J Med. 2010;5:4847.

12. Hoffbrand AV, Moss PAH, Pettit JE. Editors Blood transfusion. In: Essential Haematology. $5^{\text {th }}$ Edition Oxford: Blackwell Publishing. 2006. P 337-51

13. Webert EK, Chan HW, Smith JW, Heddle NM, Kelton JG. Red cell, platelet, and white cell antigens. In:. Greer JP, Foerster J, Lukens JN, Rodgers GM, Paraskevas F, et al, editors Wintrobe's clinical hematology 11 th edition, Philadelphia: Lippincott Williams Wilkins;2004:791-829.

14. Kumar Ganesan, Sharmila Banu Gani. Relationship between ABO, Rh Blood Groups and Diabetes Mellitus, obesity in Namakkal town, Tamilnadu. International Journal of Advances in Pharmacy, Biology and Chemistry. 2014;3(4):995-998.

15. Shikha Jaggi and Abhay Singh Yadav. Distribution of $\mathrm{ABO}$ and $\mathrm{Rh}$ (D) Allele Frequency among the type 2 Diabetes Mellitus patients. American International Journal of Research in Formal, Applied Natural Sciences. 2014;5(1):24-26.

16. Shyamal Koley. The Distribution of the ABO Blood Types in Patients with Diabetes Mellitus. Anthropologist. 2008;10(2):129-132.

17. Seema Gupta, Rajan Gupta, Gaurav Gupta, and Kush Gupta. Incidence of ABO Blood Group in Type 2 Diabetes Mellitus in Western Uttar Pradesh, India. Res $J$ Pharm Biol Chem Sci. 2015; 6(5):1039-43.

How to cite this article: Sankanagoudar $S$, Mali S. Frequency of ABO blood group and Rhesus factor (D) in patients of type 2 diabetes mellitus attending tertiary care teaching hospital of South India. Int J Clin Biochem Res. 2018;5(3):383-385. 